\title{
Epidemiological situation of bovine brucellosis in the state of Paraiba, Brazil
}

\author{
Situação epidemiológica da brucelose bovina no \\ Estado da Paraíba, Brasil
}

\author{
Inácio José Clementino ${ }^{1}$; Ricardo Augusto Dias²; Marcos Amaku²; Fernando \\ Ferreira $^{2}$; Evelise Oliveira Telles²; Marcos Bryan Heinemann²; Vítor Salvador \\ Picão Gonçalves ${ }^{3}$; José Henrique Hildebrand Grisi-Filho²; José Soares Ferreira \\ Neto $^{2}$; Clebert José Alves ${ }^{4}$; Carolina de Sousa Américo Batista Santos ${ }^{5}$; Sérgio \\ Santos de Azevedo ${ }^{4 *}$
}

\begin{abstract}
This study was performed to characterize the epidemiological status of brucellosis in the State of Paraíba, Brazil. The State was divided into three regions. Herds were randomly sampled in each region and a pre-established number of animals were sampled in each of these herds. A total of 3,489 serum samples from 674 herds were collected. In each herd, an epidemiological questionnaire was conducted. This questionnaire focused on herd traits, as well as husbandry and sanitary practices that could be associated with the risk of infection. The serum samples were screened for antibodies against Brucella spp. by the Rose-Bengal Test (RBT), and all positive sera were confirmed by the 2-mercaptoethanol test (2-ME). The herd was considered positive if at least one animal had positive results for both the RBT and the 2-ME test. The prevalence rates of infected herds and animals in the State were 4.6\% [3.2-6.5\%] and $2.5 \%$ [1.1-3.9\%], respectively. The prevalence rates of infected herds and animals in the regions were, respectively: region $1,3.2 \%$ [1.5-6.6\%] and $1.7 \%$ [0.5-5.7\%]; region $2,2.2 \%[0.9-5.2 \%]$ and $0.7 \%[0.3-$ $1.7 \%]$; and region 3, 7.9\% [5.0-12.2\%] and 3.2\% [1.6-6.3\%]. The risk factor (odds ratio, OR) associated with the presence of the infection was Zebuine as the predominant breed (OR=12.30 [1.32-114.64]).

Key words: Cattle. Brucellosis. Prevalence. Risk factors. Paraíba. Brazil.
\end{abstract}

\section{Resumo}

Realizou-se um estudo para caracterizar a situação epidemiológica da brucelose bovina no Estado da Paraíba. O Estado foi dividido em três regiões. Em cada região foram amostradas aleatoriamente propriedades e, dentro dessas, foi escolhido de forma aleatória um número pré-estabelecido de animais. No total, foram amostrados 3.489 animais, provenientes de 674 propriedades. Em cada propriedade

\footnotetext{
${ }^{1}$ Discente, Programa de Pós-Graduação em Medicina Veterinária, Universidade Federal de Campina Grande, UFCG, Patos, PB, Brasil. E-mail: clementinoij@yahoo.com.br

2 Profs., Programa de Pós-Graduação em Epidemiologia Experimental Aplicada às Zoonoses, Universidade de São Paulo, USP, São Paulo, SP, Brasil. E-mail: dias@vps.fmvz.usp.br; amaku@vps.fmvz.usp.br; fernando@vps.fmvz.usp.br; bufalo@usp.br; marcosbryan@usp.br; grisi@vps.fmvz.usp.br; jsoares@vps.fmvz.usp.br

3 Prof., Programa de Pós-Graduação em Ciência Animal, Faculdade de Agronomia e Medicina Veterinária, Universidade de Brasília, UNB, Brasília, DF, Brasil. E-mail: vitorspg@unb.br

${ }^{4}$ Profs., Programa de Pós-Graduação em Medicina Veterinária, Universidade Federal de Campina Grande, UFCG, Patos, PB, Brasil. E-mail: clebertja@uol.com.br; sergio@vps.fmvz.usp.br

${ }^{5}$ Porfa, Universidade Federal da Paraíba, UFPB, Areia, PB, Brasil. E-mail: carolamerico@yahoo.com.br

* Author for correspondence
} 
amostrada foi aplicado um questionário epidemiológico para verificar o tipo de exploração e as práticas de criação e sanitárias que poderiam estar associadas ao risco de infecção pela doença. O protocolo de testes utilizado foi o da triagem com o teste do antígeno acidificado tamponado (AAT) e confirmação dos positivos com o teste do 2-mercaptoetanol (2-ME). O rebanho foi considerado positivo quando pelo menos um animal foi reagente às duas provas sorológicas. Para o Estado, as prevalências de focos e de animais infectados foram, respectivamente, de 4,6\% [3,2-6,5\%] e 2,5\% [1,1-3,9\%]. Para as regiões, as prevalências de focos variaram entre $2,2 \%$ e $7,9 \%$ e $3,2 \%$. O fator de risco associado à condição de foco foi ter a raça Zebu como predominante $(\mathrm{OR}=12,30$ [1,32-114,64]). Concluindo, o estado da paraíba deve concentrar esforços para vacinar, todos os anos, um mínimo de $80 \%$ das bezerras com a amostra B19 e estimular a utilização da vacina RB51 em fêmeas não vacinadas com idade superior a 8 meses. Além disso, deve-se estimular a realização de testes sorológicos para brucelose nos bovinos de reprodução antes de introduzi-los nas propriedades.

Palavras-chave: Bovino. Brucelose. Prevalência. Fatores de risco. Paraíba. Brazil.

\section{Introduction}

The State of Paraíba is located in northeastern Brazil, occupying an area of approximately $56,500 \mathrm{~km}^{2}$. The area is divided geographically into four mesoregions (Agreste, Borborema, Mata Paraibana, and Sertão), 23 micro-regions, and 223 municipalities. The area contains 1,334,172 cattle, belonging to 65,805 farmers and distributed throughout 54,357 farms (GEDA, in October 2013, Agricultural Defense of Paraíba). In 2011, the production of milk in Paraíba was estimated to be the $8^{\text {th }}$ largest in the northeast, and the $19^{\text {th }}$ largest in the entire country (BRASIL, 2011). In 2009, the productive chain of livestock and fisheries accounted for $2 \%$ of the gross domestic product of Paraíba (IDEME, 2011).

Bovine brucellosis was present throughout the Brazilian territory (PAULIN; FERREIRA NETO, 2003). However, the epidemiological situation of the disease was not well known in the country, and it was only with the implementation of the National Program for Control and Eradication of Brucellosis and Tuberculosis (PNCEBT) in 2001 (LAGE, 2006) that the Brazilian States started performing epidemiological surveys of bovine brucellosis in order to determine the prevalence of infected herds and positive animals, as well as to identify risk factors. To date, epidemiological studies have been conducted in 17 states, finding a prevalence of infected herds between $0.32 \%$ in Santa Catarina and $41.5 \%$ in Mato Grosso do Sul (ALMEIDA et al., 2016; ALVES et al., 2009, AZEVEDO et al., 2009; BORBA et al., 2013; CHATE et al., 2009; DIAS et al., 2009a, 2009b; GONÇALVES et al., 2009a, 2009b; KLEIN-GUNNEWIEK et al., 2009; MARVULO et al., 2009; NEGREIROS et al., 2009; OGATA et al., 2009; ROCHA et al., 2009; SIKUSAWA et al., 2009; SILVA et al., 2009; VILLAR et al., 2009).

The states of São Paulo, Minas Gerais, Espirito Santo, Rondônia, Mato Grosso, Mato Grosso do Sul, and Rio Grande do Sul conducted the second brucellosis prevalence study to verify the effectiveness of their immunization programs. However, only in Mato Grosso, Mato Grosso do Sul, Minas Gerais and Rondônia there was a decreased prevalence of infected herds (BARDDAL et al., 2016; DIAS et al., 2016; ANZAI et al., 2016; INLAMEA et al., 2016; LEAL FILHO et al., 2016; OLIVEIRA et al., 2016; SILVA et al., 2016). The state of Santa Catarina, which had the lowest prevalence of infected herds and animals, prohibited vaccination and began the implementation of eradication strategies, and had, additionally, conducted a second study, which did not indicate changes in prevalence (BAUMGARTEN et al., 2016).

In the state of Paraíba, serological studies on the occurrence of bovine brucellosis were conducted (ALVES et al., 2003; LEITE et al., 2003; FIGUEIREDO et al., 2011; OLIVEIRA et al., 2013). However, the sample designs employed were 
not adequate for the identification of the prevalence of infected herds and seropositive animals. Thus, this study aims to determine the prevalence of infected herds and seropositive animals, identify risk factors for bovine brucellosis in the State, and provide information for better implementation and management of the National Program for Control and Eradication of Brucellosis and Tuberculosis (PNCEBT).

\section{Materials and Methods}

The study was designed by experts from the Ministry of Agriculture, Livestock and Supply, from the University of São Paulo, the University of Brasilia, in collaboration with the Federal University of Campina Grande and Agricultural Defense of Paraíba. Fieldwork was carried out by technicians from Paraíba Agricultural Defense from September 2012 to January 2013.

To test for heterogeneity in the epidemiological parameter of bovine brucellosis, the state of Paraíba was divided into regions. For the conduction of field activities according to areas of expertise of these regional units, their mesoregions, as well as the operational, logistical, and financial capacities of the official veterinary service of the State were taken into account.

In each region, the prevalence of properties infected by bovine brucellosis and seropositive animals was estimated through a sample study carried out in two stages to detect brucellosis infected herds. In the first stage, a predetermined number of properties with reproductive activity were chosen at random (primary sampling units) and in the second, a predetermined number of cows aged 24 months or greater were chosen (secondary units sampling).

In farms with more than one flock, the herd of greater economic importance was chosen as the target of the study, in which the animals were subjected to the same type of management, i.e., under the same risk factors. The choice of the primary sampling unit was random, and was based upon the registration of farms with reproductively active cattle. The properties drawn and that, for various reasons, could not be visited, were replaced by another nearby property with the same production characteristics. The number of properties drawn by region was determined by the formula for simple random samples (THRUSFIELD, 2007). The parameters adopted for the calculation were as follows: confidence level of 0.95 , estimated prevalence of 0.25 , and 0.05 error. The operational and financial capacity of the national veterinary service of the State was also taken into consideration for determining the sample size by region.

For secondary units, a minimum number of animals to be examined within each property was estimated to allow for its classification as a herd that was infected, or not, by brucellosis. Therefore, we used the concepts of sensitivity and specificity aggregates (DOHOO et al., 2003). For the purposes of calculation, values of $95 \%$ and $99.5 \%$ were adopted for the sensitivity and specificity of the test protocols used, respectively (FLETCHER et al., 1998), with $20 \%$ being selected for the estimated intra-herd prevalence. In this process, the Herdacc program version 3 was utilized, and the sample size was chosen, enabling sensitivity and specificity measurements of the herd greater than, or equal to, $90 \%$. Thus, in properties with up to 99 females older than 24 months, 10 animals were samples, and in those with 100 or more females older than 24 months, 15 animals were sampled. The choice of females within the properties was casual systematic. Females that were in the peripartum period or were post-abortion, or about 15 days before and after delivery or abortion, were excluded from the selection.

The protocol for serodiagnosis consisted of screening with the buffered, acidified antigen test (Rose Bengal) followed by retesting of positive sera with 2-mercaptoethanol according to the recommendations by PNCEBT (LAGE, 2006). The 
blood $(10 \mathrm{ml})$ was collected by puncturing the jugular vein with a sterile, disposable needle in a previously identified vacuum tube. The sera were stored in plastic wells at $-20{ }^{\circ} \mathrm{C}$ until testing. Serological tests were performed at the Communicable Disease Laboratory of the Health Center and Rural Technology of the Federal University of Campina Grande (LDT/ CSTR/ UFCG) in Patos, PB.

The property was considered positive when at least one positive animal was detected. The properties that showed animals with inconclusive serologic results with no positives were classified as suspected, and excluded from the analysis. The same protocol was applied to animals with inconclusive serological results.

The sample design allowed us to determine the prevalence of infected herds and adult females ( $\geq 24$ months) that were seropositive for brucellosis in the State and regions. Calculations of apparent prevalence and confidence intervals were performed with the aid of the Epilnfo 6.04 program (DEAN et al., 1994). The calculations for the prevalence of infected herds and animals in the State, and of the animal prevalence within the regions, were made using weighted values (DOHOO et al., 2003).

The weight of each property in calculating the prevalence of infected herds in the state was given by

$$
P_{1}=\frac{\text { properties } \dot{n} \text { the region }}{\text { properties sampled } \dot{n} \text { the region }}
$$

The weight of each animal in the calculation of the prevalence of animals in the State was given by

$$
\begin{aligned}
& P_{2}=\frac{\text { females } \geq 24 \text { months } i n \text { the property }}{\text { females } \geq \text { months sampled } i \text { the property }} * \text {, } \\
& * \frac{\text { females } \geq 24 \text { months } i \text { the region }}{\text { females } \geq 24 \text { months sampled } i n \text { the region }}
\end{aligned}
$$

In the above expression, the first term refers to the weight of each animal in the calculation of the prevalence of animals in the region.

In each sample property, in addition to collecting blood for serology, an epidemiological questionnaire was also conducted. This was intended to obtain information on the type of farming and management practices employed in order to allow for the study of risk factors associated with the presence of brucellosis.

The variables analyzed were: type of operation (or production system: meat, milk and mixed), type of creation (confined, semi-confined, extensive), type and number of milkings, use of artificial insemination, predominant races, number of cows older than 24 months, number of cattle on the property, the presence of other domestic species, the presence of wild animals, destination of placenta and of aborted fetuses, the purchase and sale of animals, vaccination against brucellosis, the slaughtering of animals on the property, rental of pastures, common pastures with other properties, flooded pastures, lambing paddock, veterinary care and the property type (Indian village, settlement, classic rural and urban periphery).

The variables were organized by increasing scale of risk. When necessary, these variables were re-categorized. The lower risk category was used as a basis for comparison with the other categories; quantitative variables were re-categorized into percentiles.

A first exploratory data analysis (univariate) for selection of those with $\mathrm{p} \leq 0.20$ by Fisher's exact test, or $\chi^{2}$, was conducted and subsequently applied to logistic regression. The calculations were performed with SPSS version 9.0. 


\section{Results}

The state of Paraíba was divided into three regions (Figure 1). Table 1 shows the census data and sample studied in each region. The results of the prevalence of bovine brucellosis infected herds in the State of Paraíba and regions are shown in Table 2. The prevalence of infected herds, by the farming type of the property, is shown in Table 3, and the prevalence of animals in Table 4.

Figure 1. Map of the State of Paraiba with divisions into regions (production circuits).

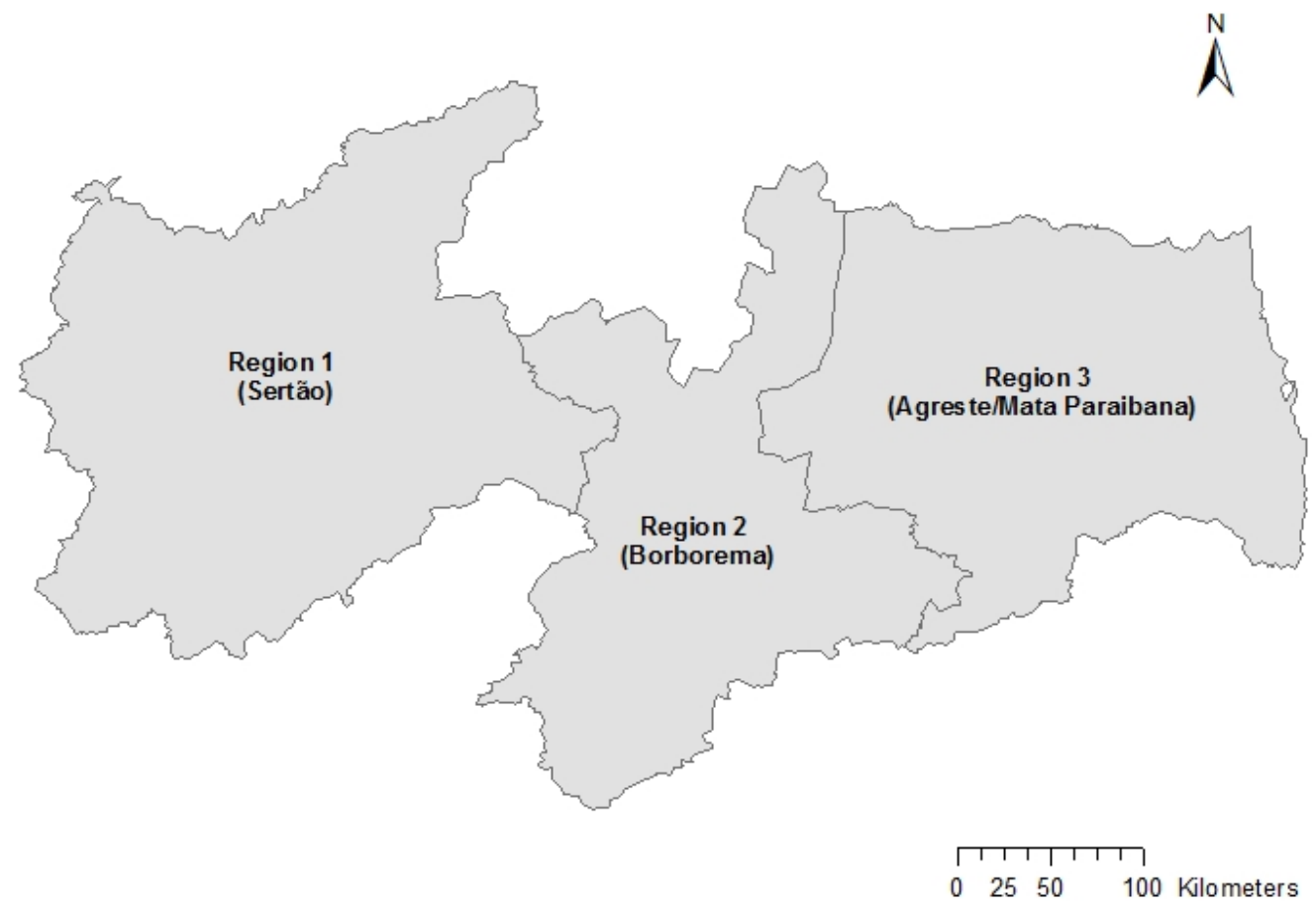

Table 1. Census data of the bovine population of the State of Paraíba state in 2012 according to region.

\begin{tabular}{cccccc}
\hline \multirow{2}{*}{ Region } & \multicolumn{2}{c}{ Properties with reproductive activity } & & \multicolumn{2}{c}{ Females older than $\geq 24$ months } \\
\cline { 2 - 3 } \cline { 5 - 6 } & Total & Sampled & & Total & Sampled \\
\hline 1 & 24.356 & 219 & & 288.764 & 1.337 \\
2 & 11.603 & 227 & & 83.428 & 1.060 \\
3 & 18.398 & 228 & & 192.320 & 1.092 \\
State & 54.357 & 674 & & 564.512 & 3.489 \\
\hline
\end{tabular}

Table 2. Prevalence of infected herds with bovine brucellosis according to region in the State of Paraíba in 2013.

\begin{tabular}{|c|c|c|c|c|}
\hline \multirow{2}{*}{ Region } & \multicolumn{2}{|c|}{ Properties } & \multirow{2}{*}{ Prevalence $(\%)$} & \multirow{2}{*}{ CI 95\% (\%) } \\
\hline & Tested & Positive & & \\
\hline 1 & 219 & 7 & 3.2 & {$[1.5-6.6]$} \\
\hline 2 & 227 & 5 & 2.2 & {$[0.9-5.2]$} \\
\hline 3 & 228 & 18 & 7.9 & {$[5.0-12.2]$} \\
\hline State & 674 & 30 & 4.6 & {$[3.2-6.5]$} \\
\hline
\end{tabular}


In the analysis of risk factors, the variables most associated ( $\mathrm{p} \leq 0.20)$ with the brucellosis infection in the univariate analysis (Table 5) were as follows: region, number of milkings, predominant race, presence of horses, the purchase of animals at auction, the sale of animals at auction, and type of property. In the final model of logistic regression, only Zebu, which was the predominant breed, was identified as a risk factor (odds ratio $=12.30 ; 95 \%$ $\mathrm{CI}=1.32$ to $114.64, \mathrm{p}=0.028)$.

Table 3. Prevalence (Prev) of infected herds with bovine brucellosis stratified by type of operation, according to region in the state of Paraíba in 2013.

\begin{tabular}{|c|c|c|c|c|c|c|}
\hline \multirow{3}{*}{ Region } & \multicolumn{6}{|c|}{ Type of usage } \\
\hline & \multicolumn{2}{|c|}{ Corte } & \multicolumn{2}{|c|}{ Milk } & \multicolumn{2}{|c|}{ Mixed } \\
\hline & Prev (\%) & CI 95\% (\%) & Prev (\%) & CI 95\% (\%) & Prev (\%) & CI 95\% (\%) \\
\hline 1 & 0 & {$[0-33.6]$} & 2.4 & {$[0.3-15.5]$} & 3.6 & {$[1.6-7.7]$} \\
\hline 2 & 0 & {$[0-13.2]$} & 5.5 & {$[2.1-13.8]$} & 0 & {$[0-2.9]$} \\
\hline 3 & 12.0 & {$[5.5-24.3]$} & 6.7 & {$[2.8-15.1]$} & 6.8 & {$[3.3-13.6]$} \\
\hline
\end{tabular}

Table 4. Prevalence cattle seropositive for brucellosis according to region in the state of Paraíba in 2013.

\begin{tabular}{|c|c|c|c|c|}
\hline \multirow{2}{*}{ Region } & \multicolumn{2}{|c|}{ Animals } & \multirow{2}{*}{ Prevalence $(\%)$} & \multirow{2}{*}{ IC 95\% (\%) } \\
\hline & Tested & Positives & & \\
\hline 1 & 1.337 & 11 & 1.7 & {$[0.5-5.7]$} \\
\hline 2 & 1.060 & 8 & 0.7 & {$[0.3-1.7]$} \\
\hline 3 & 1.092 & 24 & 3.2 & {$[1.6-6.3]$} \\
\hline State & 3.489 & 43 & 2.0 & {$[1.1-3.9]$} \\
\hline
\end{tabular}

Table 5. A univariate analysis of the variables associated $(p \leq 0.20)$ with herds infected with bovine brucellosis in the state of Paraíba in 2013.

\begin{tabular}{|c|c|c|c|c|}
\hline Variable & Category & $\begin{array}{l}\text { Total No. of } \\
\text { Properties }\end{array}$ & $\begin{array}{c}\text { Number of infected } \\
\text { herds }(\%)\end{array}$ & $\mathrm{p}$ \\
\hline \multirow[t]{3}{*}{ Number of milkings } & Do not milk & 153 & $8(5.2)$ & \\
\hline & 1 times/ day & 442 & $16(3.6)$ & \\
\hline & 2 or 3 times/day & 64 & $6(9.4)$ & 0.107 \\
\hline \multirow[t]{3}{*}{ Predominant race } & European/ others & 68 & $1(1.5)$ & \\
\hline & Mixed & 543 & $22(4.1)$ & \\
\hline & Zebu & 42 & $6(14.3)$ & 0.004 \\
\hline \multirow[t]{2}{*}{ Presence of horses } & No & 316 & $7(2.2)$ & \\
\hline & Yes & 358 & $23(6.4)$ & 0.014 \\
\hline \multirow[t]{2}{*}{ Animal purchase auction } & No & 636 & $26(4.1)$ & \\
\hline & Yes & 38 & $4(10.5)$ & 0.082 \\
\hline \multirow[t]{2}{*}{ Animals sold at auction } & No & 649 & $23(3.5)$ & \\
\hline & Yes & 25 & $7(28.0)$ & $<0.001$ \\
\hline \multirow[t]{3}{*}{ Type of property } & Indian village / settlement & 38 & $1(2.6)$ & \\
\hline & Classic rural & 614 & $25(4.1)$ & \\
\hline & Urban periphery & 21 & $4(19.0)$ & 0.004 \\
\hline
\end{tabular}




\section{Discussion}

The prevalence of herds infected with brucellosis in the state of Paraíba was $4.6 \%(95 \% \mathrm{CI}=3.2$ to $6.5 \%$ ), and the highest point value was observed in Region 3 (7.9\%) (Table 2). Regarding the type of property usage (Table 3 ), the highest prevalence of infected herds was found among cattle bred for their cuts in Region 3. However, there was no significant difference between the usage types. There was a large flow of animals entering the State to participate in a large weekly animal market in Region 3 (Agreste/Mata Paraibana), in the city of Campina Grande, which could account for this higher regional prevalence evident compared to other regions.

The prevalence of seropositive animals for bovine brucellosis in the State of Paraíba was 2.0\% (from 1.1 to $3.9 \%$ ) (Table 4), which was higher than the $0.8 \%$ rate of seropositive animals quoted in the official survey conducted in 1975 (PAULIN; FERREIRA NETO, 2003), and the frequencies listed by Leite et al. (2003) and Figueiredo et al. (2011) $(0.34 \%$ and $0.36 \%$, respectively). This increase in the prevalence of seropositive animals for bovine brucellosis may be due to the absence of an effective program to control this disease in the state of Paraíba, in addition to the acquisition of cattle breeders from other regions of the country without conducting a precautionary brucellosis test. Moreover, the state of Paraiba implemented a bovine brucellosis vaccination program only in 2008 (PARAÍBA, 2008). However, vaccination coverage between 2008 and 2012 remained below $30 \%$ (FIGUEIREDO et al., 2011). It should be noted that sampling of previous studies conducted in Paraíba was not planned following the mold of other PNCEBT studies (POESTER et al., 2009).

The final model of logistic regression indicated that Zebu was the predominant race at risk. Zebu are bred mainly for their cuts, and, in Paraíba, are concentrated mainly in Region 3 (mesoregions of Agreste and Mata Paraibana), the region with the highest prevalence of bovine brucellosis (Table
2) and with a large influx of animals. Properties that bred cattle for their cuts exhibited a greater average flock size (17 animals) compared to milk and mixed-use properties (11 and 10 affected cattle, respectively). Properties with a great number of animals tended to introduce new animals more often, a practice that, without sanitary precautions, may predispose the introduction of brucellosis into the herd (NEGREIROS et al., 2009). Thus, it is believed that the predominance of Zebu within a herd can act as an indirect indicator to the frequent, introductory flow of new animals, with this reason being the true risk factor for the introduction of bovine brucellosis into the herds of the State of Paraiba This notion was also reported by Villar et al. (2009) regarding the state of Rondônia.

\section{Conclusions}

Based on these results, it is recommended that efforts should be made to vaccinate a minimum of $80 \%$ of the calf population between three and eight months of age with the B19 sample (AMAKU et al., 2009), and vaccination of females aged 8 months and above with RB51 should be encouraged, if not previously vaccinated with B19 (SOUZA et al., 2016). Furthermore, serological tests for brucellosis in breeding cattle should be encouraged before introducing them into the properties.

\section{Acknowledgements}

The authors acknowledge the logistical and financial support from MAPA, Defesa Agropecuária da Paraíba, CNPq and FAPESP.

\section{References}

ALMEIDA, E. C.; FREITAS, A. A.; PONTUAL, K. A. Q.; SOUZA, M. M. A.; AMAKU, M.; DIAS, R. A.; FERREIRA, F.; TELLES, E. O.; HEINEMANN, M. B.; GONÇALVES, V. S. P.; EVÊNCIO NETO, J.; MARVULO, M. F. V.; GRISI-FILHO, J. H. H.; FERREIRA NETO, J. S.; SILVA, J. C. R. Prevalence and associated risk factors for bovine brucellosis in the 
state of Pernambuco, Brazil. Semina: Ciências Agrárias, Londrina, v. 37, n. 5, p. 3413-3424, 2016. Suplemento 2.

ALVES, A. J. S.; GONÇALVES, V. P. S.; FIGUEIREDO, V. C. F.; LÔBO, J. R.; BAHIENSE, L.; AMAKU, M.; FERNANDO, F.; FERREIRA NETO, J. S.; DIAS, R. A. Situação epidemiológica da brucelose bovina no Estado da Bahia. Arquivo Brasileiro de Medicina Veterinária e Zootecnia, Belo Horizonte, v. 61, p. 6-13, 2009. Suplemento 1.

ALVES, C. J.; AZEVEDO, S. S.; SANTOS, F. A.; CLEMENTINO, I. J.; FREITAS, T. D.; OLIVEIRA, A. G. F. Aspectos epidemiológicos da brucelose bovina na microrregião de Pombal, Paraíba. Agropecuária Técnica, Areia, v. 24, n. 2, p. 147-152, 2003.

AMAKU, M.; DIAS, R. A.; FERREIRA NETO, J. S.; FERREIRA, F. Modelagem matemática do controle da brucelose bovina por vacinação. Arquivo Brasileiro de Medicina Veterinária e Zootecnia, Belo Horizonte, v. 61, p. 135-141, 2009. Suplemento 1.

ANZAI, E. K.; COSTA, D.; SAID, A. L. P. R.; GRISI-FILHO, J. H. H.; AMAKU, M.; DIAS, R. A.; FERREIRA, F.; GALVIS, J. O. A.; GONÇALVES, V. S. P.; HEINEMANN, M. B.; TELLES, E. O.; FERREIRA NETO, J. S. An update on the epidemiological situation of bovine brucellosis in the state of Espírito Santo, Brazil. Semina: Ciências Agrárias, Londrina, v. 37, n. 5, p. 3437-3448, 2016. Suplemento 2.

AZEVEDO, S. S.; FERREIRA NETO, J. S.; DIAS, R. A.; FERREIRA, F.; AMAKU, M.; FIGUEIREDO, V. C. F.; LOBO, J. R.; GONÇALVES, V. S. P.; SOUZA, A. C.; VASCONCELLOS, S. A. Situação epidemiológica da brucelose bovina no Estado do Espírito Santo. Arquivo Brasileiro de Medicina Veterinária e Zootecnia, Belo Horizonte, v. 61, p. 19-26, 2009. Suplemento 1.

BARDDAL, J. E. I.; SANTOS, J. C. Q.; LOPES, I. F.; FERREIRA NETO, J. S.; FERREIRA, F.; AMAKU, M.; DIAS, R. A.; TELLES, E. O.; GRISI-FILHO, J. H. H.; HEINEMANN, M. B.; GONÇALVES, V. S. P.; AGUIAR, D. M. Effect of vaccination in lowering the prevalence of bovine brucellosis in the state of Mato Grosso, Brazil. Semina: Ciências Agrárias, Londrina, v. 37, n. 5, p. 3479-3492, 2016. Suplemento 2.

BAUMGARTEN, K. D.; VELOSO, F. P.; GRISI-FILHO, J. H. H.; FERREIRA, F.; AMAKU, M.; DIAS, R. A.; TELLES, E. O.; HEINEMANN, M. B.; GONÇALVES, V. S. P.; FERREIRA NETO, J. S. Prevalence and risk factors for bovine brucellosis in Santa Catarina State, Brazil. Semina: Ciências Agrárias, Londrina, v. 37, n. 5, p. 3425-3436, 2016. Suplemento 2.
BORBA, M. R.; STEVENSON, M. A.; GONÇALVES, V. S. P.; FERREIRANETO, J. S.; FERREIRA, F.; AMAKU, M.; TELLES, E. O.; SANTANA, S. S.; FERREIRA, J. C. A.; LÔBO, J. R.; FIGUEIREDO, V. C. F.; DIAS, R. A. Prevalence and risk-mapping of bovine brucellosis in Maranhão State, Brazil. Preventive Veterinary Medicine, Amsterdam, v. 110, n. 2, p. 169-176, 2013.

BRASIL. Pesquisa da Pecuária Municipal 2012. Sistema IBGE de Recuperação Automática (SIDRA), Instituto Brasileiro de Geografia e Estatística (IBGE). Brasília: IBGE, 2011. Disponível em <http://www.sidra.ibge.gov. $\mathrm{br} / \mathrm{bda} /$ pecua $/$ default.asp? $\mathrm{t}=2 \& \mathrm{z}=\mathrm{t} \& \mathrm{o}=24 \& \mathrm{u} 1=1 \& \mathrm{u} 2=$ $1 \& u 3=1 \& u 4=1 \& u 5=1 \& u 6=1 \& u 7=1>$. Acesso em: 11 dez. 2013.

CHATE, S. C.; DIAS, R. A.; AMAKU, M.; FERREIRA, F.; MORAES, G. M.; COSTA NETO, A. A.; MONTEIRO, L. A. R. C.; LÔBO, J. R.; FIGUEIREDO, V. C. F.; GONÇALVES, V. S. P.; FERREIRA NETO, J. S. Situação epidemiológica da brucelose bovina no Estado do Mato Grosso do Sul. Arquivo Brasileiro de Medicina Veterinária e Zootecnia, Belo Horizonte, v. 61, p. 46-55, 2009. Suplemento 1.

DEAN, A. G.; DEAN, J. A.; COLOMBIER, D. EpiInfo, version 6: a word processing database and statistics program for epidemiology on microcomputers. Atlanta: CDC, 1994. $601 \mathrm{p}$.

DIAS, J. A.; MÜLLER, E. E.; DIAS, R. A.; FREITAS, J. C.; AMAKU, M.; FERREIRA, F.; SILVA, M. C. P.; LÔBO, J. R.; FIGUEIREDO, V. C. F.; GONÇALVES, V. S. P.; FERREIRA NETO, J. S. Situação epidemiológica da brucelose bovina no Estado do Paraná. Arquivo Brasileiro de Medicina Veterinária e Zootecnia, Belo Horizonte, v. 61, p. 66-76, 2009a. Suplemento 1.

DIAS, R. A.; BELCHIOR, A. P. C.; FERREIRA, R. S.; GONÇALVES, R. C.; AGUIAR, R. S. C. B.; SOUSA, P. R.; SANTOS, A. M. A.; AMAKU, M.; FERREIRA, F.; TELLES, E. O.; GRISI-FILHO, J. H. H.; HEINEMANN, M. B.; GONÇALVES, V. S. P.; FERREIRA NETO, J. S. Controlling bovine brucellosis in the state of São Paulo, Brazil: results of ten years of vaccination program. Semina: Ciências Agrárias, Londrina, v. 37, n. 5, p. 3505-3518, 2016. Suplemento 2.

DIAS, R. A.; GONÇALVES, V. S. P.; FIGUEIREDO, V. C. F.; LÔBO, J. R.; LIMA, Z. M. B.; PAULIN, L. M. S.; GUNNEWIEK, M. F. K.; AMAKU, M.; FERREIRA NETO, J. S.; FERREIRA, F. Situação epidemiológica da brucelose bovina no Estado de São Paulo. Arquivo Brasileiro de Medicina Veterinária e Zootecnia, Belo Horizonte, v. 61, p. 118-125, 2009b. Suplemento 1. 
DOHOO, I.; MARTIN, W.; STRYHN, H. Veterinary epidemiologic research. Charlottetown: Atlantic Veterinary College, 2003. 706 p.

FIGUEIREDO, S. M.; ROCHA, V. C. M.; HIGINO, S. S. S.; BATISTA, C. S. A.; ALVES, C. J.; CLEMENTINO, I. J.; AZEVEDO, S. S. Brucelose bovina no estado da Paraíba: estudo retrospectivo. Arquivos do Instituto Biológico, São Paulo, v. 78, n. 1, p. 9-16, 2011.

FLETCHER, R. H.; FLETCHER, S. W.; WAGNER, E. H. Clinical epidemiology: the essentials. $2^{\text {th }}$ ed. Baltimore: Williams and Wilkins, 1998. $246 \mathrm{p}$.

GONÇALVES, V. S. P.; DELPHINO, M. K. V. C.; DIAS, R. A.; FERREIRA, F.; AMAKU, M.; FERREIRA NETO, J. S.; PORTO, T. B.; ALVES, C. M.; FIGUEIREDO, V. C. F.; LÔBO, J. R. Situação epidemiológica da brucelose bovina no Estado de Minas Gerais. Arquivo Brasileiro de Medicina Veterinária e Zootecnia, Belo Horizonte, v. 61, p 35-45, 2009a. Suplemento 1.

GONÇALVES, V. S. P.; RIBEIRO, L. A.; CALDAS, R. A.; FRANCISCO, P. F. C.; DIAS, R. A.; FERREIRA, F.; AMAKU, M.; FERREIRA NETO, J. S.; FIGUEIREDO, V. C. F.; LÔBO, J. R.; BORGES, J. R. J. Situação epidemiológica da brucelose bovina no Distrito Federal. Arquivo Brasileiro de Medicina Veterinária e Zootecnia, Belo Horizonte, v. 61, p. 14-18, 2009b. Suplemento 1.

INLAMEA, O. F.; ROCHA, A. B.; FERREIRA, F.; GRISI-FILHO, J. H. H.; HEINEMANN, M. B.; DIAS, R. A.; TELLES, E. O.; GONÇALVES, V. S. P.; AMAKU, M.; FERREIRA NETO, J. S. Effect of vaccination in lowering bovine brucellosis in the state of Rondônia, Brazil. Semina: Ciências Agrárias, Londrina, v. 37, n. 5, p. 3493-3506, 2016. Suplemento 2.

INSTITUTO DE DESENVOLVIMENTO MUNICIPAL E ESTADUAL - IDEME e IBGE publicam os resultados do PIB em 2009. João Pessoa: IDEME, 2011. Disponível em $\quad<$ http://ideme.pb.gov.br/index.php/objetivosdo-milenio/doc_details/1444-nota-tecnica-pib-dosmunicipios-2009.html . Acesso em 20 nov. 2013.

KLEIN-GUNNEWIEK, M. F. C.; AMAKU, M.; DIAS, R. A.; FERREIRA, F.; GITTI, C. B.; PEREIRA, L. A; FIGUEIREDO, V. C. F.; LOBO, J. R.; GONÇALVES, V. S. P.; FERREIRA NETO, J. S. Situação epidemiológica da brucelose bovina no Estado do Rio de Janeiro. Arquivo Brasileiro de Medicina Veterinária e Zootecnia, Belo Horizonte, v. 61, p. 77-84, 2009. Suplemento 1.

LAGE, A. P.; ROXO, E.; MÜLLER, E.; POESTER, F.; CAVALLÉRO, J. C. M.; FERREIRA NETO, J. S.; MOTA, P. M. P. C.; GONÇALVES, V. S. P. Programa nacional de controle e erradicação da brucelose e da tuberculose animal (PNCEBT). Brasília: Ministério da
Agricultura, Pecuária e Abastecimento, 2006, 184 p. (Manual técnico, 1).

LEAL FILHO, J. M.; BOTTENE, I. F. N.; MONTEIRO, L. A. R. C.; PELLEGRIN, A. O.; GONÇALVES, V. S. P.; FERREIRA, F.; DIAS, R. A.; AMAKU, M.; TELLES, E. O.; GRISI-FILHO, J. H. H.; HEINEMANN, M. B.; FERREIRA NETO, J. S Control of bovine brucellosis from 1998 to 2009 in the state of Mato Grosso do Sul, Brazil. Semina: Ciências Agrárias, Londrina, v. 37, n. 5, p. 3467-3478, 2016. Suplemento 2.

LEITE, R. M. H.; THOMPSON, J. A.; GONÇALVES, V. S. P.; LEITE, R. C.; BANDEIRA, D. A.; LAGE, A. P. A random sample survey of bovine brucellosis in the State of Paraíba, Brazil. Brazilian Journal of Veterinary Research and Animal Science, São Paulo, v. 40, p. 170174, 2003. Supplement 3.

MARVULO, M. F. V.; FERREIRA, F.; DIAS, R. A.; AMAKU, M.; GROFF, A. C. M.; GONÇALVES, V. S. P.; FIGUEIREDO, V. C. F.; LOBO, J. R.; FERREIRA NETO, J. S. Situação epidemiológica da brucelose bovina no Estado do Rio Grande do Sul. Arquivo Brasileiro de Medicina Veterinária e Zootecnia, Belo Horizonte, v. 61, p. 93-102, 2009. Suplemento 1.

NEGREIROS, R. L.; DIAS, R. A.; FERREIRA, F.; FERREIRA NETO, J. S.; GONÇALVES, V. S. P.; SILVA, M. C. P.; FIGUEIREDO, V. C. F.; LÔBO, J. R.; FREITAS, J.; AMAKU, M. Situação epidemiológica da brucelose bovina no Estado do Mato Grosso. Arquivo Brasileiro de Medicina Veterinária e Zootecnia, Belo Horizonte, v. 61, p. 56-65, 2009. Suplemento 1.

OGATA, R. A.; GONÇALVES, V. S. P.; FIGUEIREDO, V. C. F.; LOBO, J. R.; RODRIGUES, A. L.; AMAKU, M.; FERREIRA, F.; FERREIRA NETO, J. S.; DIAS, R. A. Situação epidemiológica da brucelose bovina no Estado do Tocantins. Arquivo Brasileiro de Medicina Veterinária e Zootecnia, Belo Horizonte, v. 61, p. 126134, 2009. Suplemento 1.

OLIVEIRA, L. F.; DORNELES, E. M. S.; MOTA, A. L. A. A.; GONÇALVES, V. S. P.; FERREIRA NETO, J. S.; FERREIRA, F.; DIAS, R. A.; TELLES, E. O.; GRISIFILHO, J. H. H.; HEINEMANN, M. B.; AMAKU, M.; LAGE, A. P. Seroprevalence and risk factors for bovine brucellosis in the State of Minas Gerais, Brazil. Semina: Ciências Agrárias, Londrina, v. 37, n. 5, p. 3449-3446, 2016. Suplemento 2.

OLIVEIRA, R. M.; SILVA, M. L. C. R.; MACÊDO, M. M. S.; HIGINO, S. S. S.; PAULIN, L. M.; ALVES, C. J.; CARVALHO, M. G. X.; AZEVEDO, S. S. Soroepidemiologia da leptospirose e brucelose bovina em propriedades rurais de agricultura familiar do agreste 
paraibano, Nordeste do Brasil. Arquivos do Instituto Biológico, São Paulo, v. 80, n. 3, p. 303-311, 2013.

PARAÍBA. Portaria ${ }^{0}$ 062, de 12 de maio de 2008. Dispõe sobre a obrigatoriedade da vacinação contra brucelose de fêmeas bovinas e bubalinas no Estado da Paraíba e dá outras providências. Diário Oficial [do] Estado da Paraíba, n. 13.805, Poder Executivo, João Pessoa, PB, 16 maio 2008. Seção 1, p. 2.

PAULIN, L. M.; FERREIRA NETO, J. S. A Experiência brasileira no combate à brucelose bovina. Jaboticabal: FUNEP, 2003. $154 \mathrm{p}$.

POESTER, F.; FIGUEIREDO, V. C. F.; LÔBO, J. R.; GONÇALVES, V. S. P.; LAGE, A. P.; ROXO, E.; MOTA, P. M. P. C.; MÜLLER, E. E.; FERREIRA NETO, J. S. Estudos de prevalência da brucelose bovina no âmbito do programa nacional de controle e erradicação de brucelose e tuberculose: introdução. Arquivo Brasileiro de Medicina Veterinária e Zootecnia, Belo Horizonte, v. 61, p. 1-5, 2009. Suplemento 1.

ROCHA, W. V.; GONÇALVES, V. S. P.; COELHO, C. G. N. F. L.; BRITO, W. M. E. D.; DIAS, R. A.; DELPHINO, M. K. V. C.; FERREIRA, F.; AMAKU, M.; FERREIRA NETO, J. S.; FIGUEIREDO, V. C. F.; LÔBO, J. R.; BRITO, L. A. B. Situação epidemiológica da brucelose bovina no Estado de Goiás. Arquivo Brasileiro de Medicina Veterinária e Zootecnia, Belo Horizonte, v. 61, p. 27-34, 2009. Suplemento 1.

SIKUSAWA, S.; AMAKU, M.; DIAS, R. A.; FERREIRA NETO, J. S.; MARTINS, C.; GONÇALVES, V. S. P.; FIGUEIREDO, V. C. F.; LOBO, J. R.; FERREIRA, F. Situação epidemiológica da brucelose bovina no Estado de Santa Catarina. Arquivo Brasileiro de Medicina Veterinária e Zootecnia, Belo Horizonte, v. 61, p. 103108, 2009. Suplemento 1.
SILVA, N. S.; GROFF, A. C. M.; VIDOR, A. C. M.; GRISI-FILHO, J. H. H.; HEINEMANN, M. B.; DIAS, R. A.; TELLES, E. O.; GONÇALVES, V. S. P.; AMAKU, M.; FERREIRA, F.; FERREIRA NETO, J. S. Epidemiological situation of brucellosis after implementation of the vaccination program in Rio Grande do Sul State, Brazil. Semina: Ciências Agrárias, Londrina, v. 37, n. 5, p. 3519-3530, 2016. Suplemento 2.

SILVA, V.G. S. O.; DIAS, R.A.;FERREIRA, F.;AMAKU, M.; COSTA, E. L. S.; LOBO, J. R.; FIGUEIREDO, V. C. F.; GONÇALVES, V. S. P.; FERREIRA NETO, J. S. Situação epidemiológica da brucelose bovina no Estado de Sergipe. Arquivo Brasileiro de Medicina Veterinária e Zootecnia, Belo Horizonte, v. 61, p. 109-117, 2009. Suplemento 1.

SOUZA, V. A. F.; FERREIRA NETO, J. S.; AMAKU, M.; DIAS, R. A.; TELLES, E. O.; GRISI-FILHO, J. H. H.; HEINEMANN, M. B.; FERREIRA, F. Mathematical modeling of bovine brucellosis control using the RB51 vaccine. Semina: Ciências Agrárias, Londrina, v. 37, n. 5, p. 3767-3776, 2016. Suplemento 2.

THRUSFIELD, M. Veterinary epidemiology. $3^{\text {th }}$ ed. Oxford: Blackwell, 2007. 610 p.

VILLAR, K. S.; AMAKU, M.; DIAS, R. A.; FERREIRA NETO, J. S.; BENITEZ, F.; GONÇALVES, V. S. P.; FIGUEIREDO, V. C. F.; LÔBO, J. R.; FERREIRA, F. Situação epidemiológica da brucelose bovina no Estado de Rondônia. Arquivo Brasileiro de Medicina Veterinária e Zootecnia, Belo Horizonte, v. 61, p. 85-92, 2009. Suplemento 1. 